\title{
Risk perception related to food
}

\author{
Peter REMBISCHEVSKI ${ }^{1,2}$, Eloisa Dutra CALDAS ${ }^{3 *}$ (it)
}

\begin{abstract}
There is no human activity that is risk free, including those most trivial and essential for survival, such as eating. Various factors impact the risk perception of a population, such as whether the risk is voluntary, known, brings some benefits or whether the information about the risk is provided by sources seen as trusted. Furthermore, regional and cultural aspects, gender and age can also have an impact on risk perception, and the level of scientific knowledge of the individual about the risks has in many cases little impact on the risk perception. In most countries, the perception of consumers to certain risks present in food, including genetically modified organisms (GMO), pesticides and food additives is high, probably due to the lack of confidence on the industry and governmental authorities that are responsible to control the risks. Food that are considered more natural, such as organic food and "GMO free", are normally perceived as less risky/more healthy. Knowing the perception of the population regarding the risks present in food is essential to design clear and transparent risk communication strategies, which should consider, in addition to scientific information, the subjective aspects that affects the risk perception.
\end{abstract}

Keywords: risk perception; food; contaminants; pesticide residues; technology.

Practical Application: To help governments in their strategies of communicating to the general population about the potential risks present in food.

\section{Introduction}

The subject of risk has taken a central position in health areas in recent years, involving experts and the general population in the debate, due to the direct impacts on people's daily lives (Spencer, 2016; Castiel et al., 2010).

The term "risk" probably comes from the Greek word rhiza, in reference to the hazards of sailing around a cliff, with the possibility of scratching the ship hull (Covello \& Mumpower, 1985). More recently, risk was defined by Beck (1992) as a situation or event in which something of human value (including humans themselves) is at stake and where the outcome is uncertain. Sandman (2012) defined risk as a function of hazard and outrage $(R=f(H, O))$, where hazard can be a chemical, a bacteria or a poison gas and outrage involves factors such as trust, fairness, familiarity and memorability. For Kermisch (2012), the concepts of risk and responsibility are increasingly intertwined, a tendency that has grown by increasing public awareness, and suggested that a form of virtue-responsibility should be integrated in the concept of risk. Indeed, risk has a polysemic nature, whose objective and subjective dimensions must be understood as complementary, considering the technical and social components, being socially, culturally and mentally constructed (Covello \& Mumpower, 1985; Hansson, 2010; Völker et al., 2017).

The first risk perception studies appeared in the 1970s (Renn et al., 2001), and several definitions are available for this term. It may refer, for example, to subjective assessments of the likelihood of a particular type of incident occurring (Cho et al., 2014) or to the ability to interpret a situation of potential harm to one's health or life based on past experience and extrapolation to a future moment (Wiedemann, 1993). There are several theories or approaches to investigate risk perception within a population (Spencer, 2016). One of them is the psychometric paradigm, which initially sought to determine how people perceived technological risks in relation to their benefits, considering social and psychological contexts, seeking to answer "How safe is safe enough?" (Starr, 1969). Subsequently, Slovic et al. (1980) postulated that individuals perceive situations as safe or risky depending on the context of the risk, such as whether it is voluntary or imposed, known or unknown, whether there are benefits involved, or whether the information comes from reliable sources (Lanard, 2004; Sandman, 2012). Visschers \& Siegrist (2018) emphasized that these aspects have different impacts on risk perception to different hazards.

Food is essential for body development and life-sustaining, and health promotion and disease prevention through healthy diets have been increasingly recognized as crucial in the contemporary world (European Commission, 2014). The act of eating also has a strong social connotation, closely related to family unity, religious festivities and the most diverse forms of integration (Kaptan et al., 2018; Frewer et al., 2016). Although foods offered to the population are considered safer than in the past, episodes in recent decades, such as the mad cow disease (Bovine Spongiform Encephalopathy) in England in 1986 and Avian Influenza in Asia in 2003, have undermined consumer confidence in health and control authorities, bringing uncertainty about food safety

Received 10 Oct., 2019

Accepted 27 Nov., 2019

${ }^{1}$ Programa de Pós-Graduação em Ciências da Saúde, Universidade de Brasília - UnB, Darci Ribeiro Campus, Brasília, DF, Brasil

${ }^{2}$ Agência Nacional de Vigilância Sanitária - ANVISA, Brasília, DF, Brasil

${ }^{3}$ Laboratorio de Toxicologia, Departamento de Farmácia, Faculdade de Ciências da Saúde, Universidade de Brasília - UnB, Brasília, DF, Brasil

*Corresponding author: eloisa@unb.br 
(Bánáti, 2011). In addition to scientific information, knowledge of how consumers perceive the different risks they are exposed to in their diet and how this influences their consumption decisions is important for the design of efficient governmental risk management and communication strategies (Charlebois \& Summan, 2015; Hooker et al., 2017).

This study aimed to investigate food-related risk perception from studies conducted in the world in recent decades, a subject that is still little explored in Brazil. Food-related risk perception of genetically modified organisms (GMOs), pesticides and food additives will be discussed in more detail.

\section{Food-related risk perception}

Food-related risk perception acts by cognitive mechanisms. They may differ from non-food risks, essentially because food is a vital necessity and part of people's daily lives (Kaptan et al., 2018). Some determinants seem to be particularly important in shaping people's reactions to food risks. For example, foods of technological origin are perceived as more dangerous than natural foods (Frewer et al., 2016), although the perception of what is natural is not always the same among people (Chambers et al., 2018). Additional complexity stems from acute versus chronic risk. For example, presenting a naturally occurring risk in an acute or crisis context (such as poisoning events) may exacerbate risk perception, while technological risks are most feared for their possible (or perceived) long-term chronic effects (Glik, 2007).

Sparks \& Shepherd (1994) and Fife-Schaw \& Rowe (1996) pioneered the application of the psychometric paradigm in food-related risk perception studies. Figure 1 shows three dimensions of risk perception in light of the psychometric paradigm: natural $\mathrm{x}$ technological, controllable $\mathrm{x}$ uncontrollable and new/unknown x old/known (Breakwell, 2000). It is observed that sugar is in a high position on the knowledge and risk controllability axis and is also recognized as a natural substance.

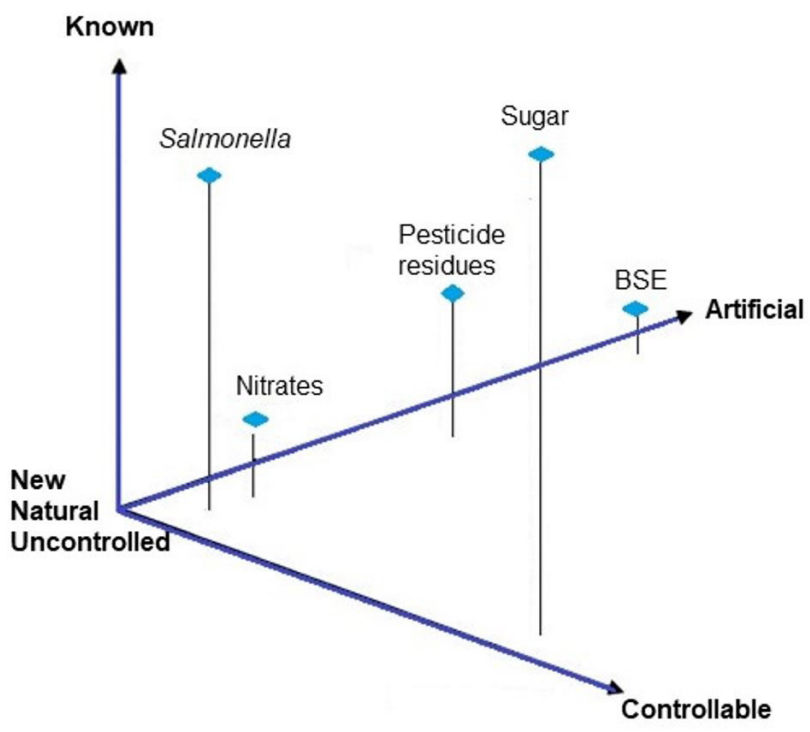

Figure 1. Three dimensions of risk perception of food hazards. Adapted from Breakwell (2000). BSE: Bovine Spongiform Encephalopathy.
However, pesticides lay in a low to moderate level of knowledge, no controllability, and more perceived as technological/artificial rather than natural in origin.

Breakwell (2000) also suggested that gender (women tend to be more aware of food risks), ethnicity, age, and geographic region may be potential sources of variation in risk perception. In South Korea, You et al. (2018) examined perceptions about four hazards (benzopyrene in noodle soup, norovirus in school cafeterias, misuse of plastic coffee bags and salmonella in children's foods) against five psychometric factors (familiarity, confidence, catastrophic potential, effect on children and dread). Confidence, catastrophic potential and dread impacted all hazards, and all factors affected norovirus-related perception. Confidence was the factor that most affected the risk perception for children's food (salmonella and norovirus).

The European Union periodically conducts a survey with several population extracts on various human activities, including perception on food-related risks, called Eurobarometer. In the 2010 Eurobarometer (European Commission, 2010), 19\% of citizens had spontaneously mentioned the presence of pesticides and other chemicals in food as factors of concern, leading the list of risks mentioned. In the most recent study conducted in April 2019, 27,655 vis-a-vis interviews were conducted in the 28 member countries (European Commission, 2019). About 40\% of respondents said they had a personal interest in food safety and $55 \%$ showed a high level of awareness about food safety. There were significant differences in risk perception across countries, but $43 \%$ of respondents believed that food products are full of harmful substances. Greater familiarity ( $72 \%$ of respondents) was observed with food additives such as colorings, preservatives and flavorings. However, the major concern was related to antibiotic, hormone or steroid residues in meat (mentioned by $44 \%$ of respondents), followed by pesticide residues (39\%), as shown in Figure 2. New topics such as microplastics first appeared on the continent's food safety radar (Figure 2).

In a study conducted with 26 European countries, Meagher (2018) suggested that national variations in risk perception are related to the influence of media coverage on food risks and adverse events, as well as strong food supply chain. Overall, there was greater attention and mobilization by activist groups on issues such as pesticides and hormones than on events of biological origin (such as the Escherichia coli outbreak in Germany in 2011). These events were perceived as more natural and personally controllable (Meagher, 2018).

Another study conducted in the European Union involved 6,000 respondents from 25 member countries and focused specifically on three emerging risks: green smoothies, plastic rice and nanotechnology (Etienne et al., 2018). Plastic rice was allegedly produced with potato, sweet potato and plastic and was widely mentioned in the media, although no real cases were identified. Results indicated that consumers tend to be more concerned with well-established risks, including fraud, than with emerging risks for which the population has little information. The study suggested that communicating information about the nature of the risk and the level of uncertainty associated with that risk could have an important impact on risk perception, mitigating or amplifying (green smoothie) that perception. 


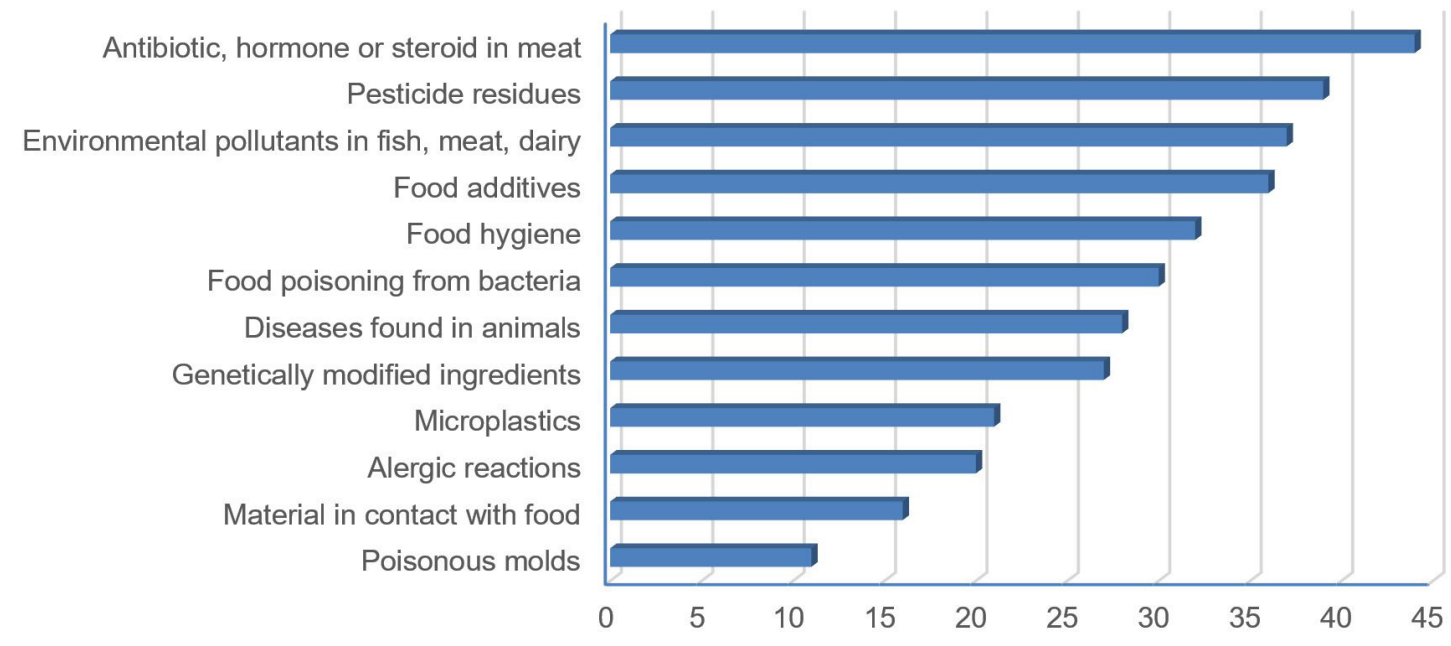

Figure 2. Main food-related topics that concern Europeans the most, \% of respondents (European Commission, 2019).

According to the Netherlands National Institute of Public Health and Environment (RIVM, Rijksinstituut voor Volksgezondheid en Milieu), Dutch consumers eating habits are based on their perceptions, which do not always correspond to scientific knowledge. In general, consumers make no distinction between safe, healthy or sustainable food. There was a high concern regarding food additives and the perception that chemical risks were greater than microbiological or natural ones (Rijksinstituut voor Volksgezondheid en Milieu, 2017). In Ghana, consumers gave equal weight to concerns about the chemical versus biological hazards, both of which are marked by the majority as very or extremely concerned (Omari et al., 2018). Respondents were less concerned about aflatoxin contamination (genotoxic toxin produced by Aspergillus sp. fungi) and food produced near mining sites; women showed a higher level of concern/risk perception for most of the food hazards assessed than men (Omari et al., 2018). In a study involving US mothers, however, chemicals were considered to be of less concern than microbiological risks (cited by 12 and $51 \%$ of respondents, respectively), but the mere mention of "chemical substances in food" affected the decision to buy food by 63.7\% of the participants (Petrun et al., 2015).

Using information obtained from 824 questionnaires in 16 Chinese cities and over 10,000 media reports on pork quality and safety, Yan et al. (2019) found that social activities coupled with media action affected consumers' perceived risk regarding traceability in the food chain, in light of the social integration theory. The "ripple effect" proposed by the Social Amplification of Risk Framework (SARF; Kasperson et al., 1988) was observed in groups that received negative food safety information from the media, but not in groups exposed to positive information.

In Brazil, food risk perception was approached by a study conducted in the city of Campinas, state of São Paulo and in the city of Rio de Janeiro, state of Rio de Janeiro through focus groups, preceded by a brief questionnaire to recruited individuals (Andrade et al., 2013). Consumer groups in both cities were very concerned about the presence of pesticides and heavy metals in food and about microbiological risks, particularly Salmonella. Meat, mainly due to hormones and nitrates/nitrites, and seafood were considered foods with the highest health risk. The latter was of higher concern by Rio de Janeiro consumers.

A large study of risk perception associated with the food chain through focus groups involved consumers in Brazil and four European countries (Poland, Ireland, the Netherlands and France) (Kher et al., 2013). Overall, chemical hazards were perceived as of greater concern than biological hazards and were strongly associated with the potential for severe consequences, long-term effects and lack of personal control to prevent them. Of particular note is the greater concern of Polish consumers about the possible risks arising from food irradiation (used to control/eliminate the presence of microorganisms), which was attributed to Poland's geographical proximity to Ukraine, where the Chernobyl nuclear disaster occurred in 1986. In the US, consumer perceptions of the food irradiation process also refer to the idea of nuclear energy/radiation, increasing the perception of individuals in this technology (Bearth \& Siegrist, 2019). When the term food ionization was used in the American study, another denomination for the same technology, the negative perception on food quality was lower. This behavior is a typical example of affect heuristics, which holds that emotions and affective relationships influence our perceptions, judgments and decision-making (Kahneman \& Frederick, 2005).

In a study conducted in Switzerland, Hartmann et al. (2018a) noted that food control experts, industry representatives and consumers reported varying degrees of prioritization for certain risks. Experts gave higher priority to day-to-day hazards such as nitrosamines in mascara and chrome in leather, while producers and consumers prioritized the risks posed by pesticides and GM foods. The authors recommended to regulatory authorities that, in addition to the objective results of the risk assessment, also consider the population's food risk perceptions in prioritizing their actions. In Australia, Tonkin et al. (2016) observed that the population positively perceives food labeling as an effective risk communication instrument, and that it is imperative that actors involved in the food system ensure labeling information reliability. Hartmann et al. (2018b) indicated that labeling a food product with the expression "free from" shapes people's perceptions, being viewed as healthier or safer by the public, as "GMO free". 


\section{GMO-related risk perception}

Although several studies have proven the safety and benefits of new technologies in the food production and industry, such as transgenic food (Bruetschy, 2019), public debate involving GMOs goes beyond science. The debate permeates sociocultural and affective contexts, and the acceptance of this technology is affected even by beliefs in food sacredness (Mallinson et al., 2018). According to Chen (2018), the rejection of food from new technologies (technological neophobia) shapes people's risk perception regarding GMOs.

In a review of European and American studies, Wunderlich \& Gatto (2015) noted that although genetically modified foods were introduced more than 2 decades ago, there is still a low level of knowledge and awareness of basic GMO concepts. This contributes to a negative view by an important portion of the population on this topic. On the other hand, individuals reported a higher level of confidence in sources of information from scientists, albeit via the internet, TV and magazines, compared to government sources, activists, industry and the media. A greater familiarity with the term GMO does not necessarily imply scientific knowledge about it but correlates with rejection of the technology and consequently a desire to pay more for non-GMO products.

In a study conducted through the application of online questionnaires, Komoto et al. (2016) noted that Japanese consumers have a higher risk perception of GMOs than British and American consumers, but lower than that of the French. Overall, women, individuals over 60, and uneducated individuals were the groups most resistant to the application of genetic modification technologies to food in the four nations. Loebnitz \& Grunert (2018) observed that abnormally shaped (deformed or very large) vegetables are seen in Germany as unnatural and GMO-related, increasing their risk perception. On the other hand, Eurobarometer results showed that Europeans are currently less concerned about GMOs when compared to the 2010 survey (European Commission, 2010, 2019).

In Brazil, a telephone poll conducted in 2016 showed that $44 \%$ of the consumers believe GM foods are poorly tested, 33\% that they are bad for their health and 29\% that they cause allergic reactions (Conselho de Informações sobre Biotecnologia, 2016). However, 73\% said they had already consumed GM foods, and of the remaining, 59\% were open to experimenting. Castro et al. (2014) assessed the public perception on GMOs involving about 800 Brazilian urban consumers from seven cities in different regions of the country. About $37 \%$ of respondents said they do not know what GM foods are, and among those who claimed to have at least a notion about the subject, a low risk perception predominated for these foods. Most of those who reported concern linked their risks to more intensive pesticide use, while advocates argued otherwise. The authors noted that there was some confusion of concepts (e.g., transgenics being confused with trans fats). They stressed the importance of separating the debate between "transgenic vs. non transgenic" and "organic vs. conventional”.

\section{Pesticide risk perception $v s$ organic food benefit}

Demand for products from organic agriculture, which do not use chemical pesticides for pest control, has been increasing worldwide since the 1990s, due to the increased environmental awareness and the perception that these foods would be healthier than conventional foods (Saba \& Messina, 2003; Koch et al., 2017; Patel, 2018).

A study conducted in Denmark confirmed consumers' perception that organic foods are healthier, which was more related to the notion of purity ("uncontaminated") than to the nutritional value or pleasure of sensory experience (Ditlevsen et al., 2019). Hilverda et al. (2018) showed that the number of positive social media comments about a food in the Netherlands decreases the perception of its risk in situations of uncertainty, especially for organic foods. In another study of the group, determinants related to risk perception to these foods were positively correlated to the information sharing process, a behavior that should be considered in risk-benefit communication task (Hilverda \& Kuttschreuter, 2018). In Germany, a computer-assisted telephone survey showed that both organic and conventional consumers viewed pesticides, chemicals, and toxins as the greatest threats to food quality and safety (Koch et al., 2017). About 70\% of the organic consumers rated the risks of pesticide use greater than the benefits, compared with $53 \%$ of the conventional consumers. Organic consumers were significantly more concern about pesticide residues in the food and in human fluids than conventional consumers.

Coulibaly et al. (2011) observed that consumers in Benin and Ghana demonstrated high perception of health risk from pesticide residues in fruits and vegetables, and were willing to pay more than $50 \%$ for pesticide-free foods. Similar results were found in a pilot study of 237 participants from the Federal District of Brazil involving outpatients, college students and supermarket consumers, when over $50 \%$ of respondents were willing to pay more for these products (Pimenta, 2003). In a more recent study conducted in the city of Belo Horizonte, state of Minas Gerais with 400 consumers, organic foods were associated with higher nutrient levels by $82 \%$ of respondents and being free of GMOs and synthetic chemicals by 75 and $86 \%$, respectively (Andrade \& Bertoldi, 2012). All related organic food consumption to health benefits and almost all (98.8\%) reported improved health as a result of this consumption.

\section{Food additives}

Although food additives are useful ingredients in the food industry, with some benefits for consumers, being strictly regulated by governmental authorities, the rejection of their presence in food is increasing in the last decades (Szücs et al., 2019; van Gunst \& Roodenburg, 2019). In the Netherlands, food experts indicated that low reliability in the food industry and preponderance of negative information about food additives on the internet and social networks are the main causes of high risk perception (van Gunst \& Roodenburg, 2019). The authors stated that forms of communication with the public, including labeling, need to be improved to overcome this barrier and increase acceptance of these substances. According to Rijksinstituut voor Volksgezondheid en Milieu (2017), an increased use of food additives will lead to a decrease in Dutch consumers' confidence in food safety. 
A study carried out in Switzerland involving around 1000 participants showed that acceptance of dyes is lower than sweeteners, and risk perception to both additives was influenced by knowledge about regulation and trust in regulators (Bearth et al., 2014). Respondents showed lower risk perception in relation to benefit, and consequently greater acceptance of substances seen as natural. In Taiwan, where a series of scandals involving the addition of illegal food additives occurred, population perceptions and consequent rejection of foods containing chemical additives were quite high and were dependent on the frequency with which scandals were reported in the media and information source credibility (Chen, 2017).

In the study conducted by Pimenta in the Federal District of Brazil (Pimenta, 2003), 64\% of consumers interviewed in supermarkets said they knew what a food additive was, but $87 \%$ considered them harmful to health, confirming that risk perception is dependent on other aspects than scientific knowledge. The same profile was observed among university students and patients (35.4/87\% and $25 / 46 \%$, respectively).

In the United States, Song \& Schwarz (2009) reported that the difficulty in pronouncing the name of food additives, real or fictitious, was related to the perception of their risk. The harder it is to pronounce, the more the substance is perceived as harmful to health. Names that are more difficult to pronounce are usually substances considered new or less well known, and once they became known, judgment of their risk would be altered. Using the same method, this thesis was challenged by a study conducted with individuals from the Czech Republic, Germany, and workers from Amazon's Mechanical Turk (Bahník \& Vranka, 2017). The authors concluded that risk perception was more related to the size of the word than to the difficulty of pronouncing it. This perception ranged according to the context and encouragement received by the individual during the questionnaire application, such as war or leisure settings, confirming the subjective aspects of risk perception.

\section{Conclusion}

This review sought to show that people's perception of food risks is multifactorial and of great complexity, depending less on objective and tentatively measurable risks than on subjective issues. These issues comprise social, cultural, psychological, ethical and moral aspects, which together constitute what we call values or worldviews. Several studies on the subject have shown that, more than the rational and decisions based on technical-scientific knowledge, the emotional and intuitive side of individuals contribute strongly to the perception of food risks and their balance in relation to the benefits obtained. In this sense, risk communication strategies focused on filling scientific knowledge gaps tend to be ineffective if not aligned with approaches that consider and respect the human dimension that permeates the universe of perceptions.

\section{References}

Andrade, J. C., Deliza, R., Yamada, E. A., Galvão, M. T. E. L., Frewer, L. J., \& Beraquet, N. J. (2013). Percepção do consumidor frente aos riscos associados aos alimentos, sua segurança e rastreabilidade.
Brazilian Journal of Food Technology, 6(3), 184-191. http://dx.doi. org/10.1590/S1981-67232013005000023.

Andrade, L. M. S., \& Bertoldi, M. C. (2012). Atitudes e motivações em relação ao consumo de alimentos orgânicos em Belo HorizonteMG. Brazilian Journal of Food Technology, 15, 31-40. http://dx.doi. org/10.1590/S1981-67232012005000034.

Bahník, S., \& Vranka, N. A. (2017). If it's difficult to pronounce, it might not be risky: the effect of fluency on judgment of risk does not generalize to new stimuli. Psychological Science, 28(4), 427-436. http://dx.doi.org/10.1177/0956797616685770. PMid:28406381.

Bánáti, D. (2011). Consumer response to food scandals and scares. Trends in Food Science \& Technology, 22(2-3), 56-60. http://dx.doi. org/10.1016/j.tifs.2010.12.007.

Bearth, A., \& Siegrist, M. (2019). "As long as it is not irradiated" Influencing factors of US consumers' acceptance of food irradiation. Food Quality and Preference, 71, 141-148. http://dx.doi.org/10.1016/j. foodqual.2018.06.015.

Bearth, A., Cousin, M. E., \& Siegrist, M. (2014). The consumer's perception of artificial food additives: Influences on acceptance, risk and benefit perceptions. Food Quality and Preference, 38, 14-23. http://dx.doi.org/10.1016/j.foodqual.2014.05.008.

Beck, U. (1992). Risk society: towards a new modernity (260 p.). London: Sage Publications.

Breakwell, G. (2000). Risk communication: factors affecting impact. British Medical Bulletin, 56(1), 110-120. http://dx.doi. org/10.1258/0007142001902824. PMid:10885109.

Bruetschy, C. (2019). The EU regulatory framework on genetically modified organisms (GMOs). Transgenic Research, 28(Suppl 2), 169174. http://dx.doi.org/10.1007/s11248-019-00149-y. PMid:31321701.

Castiel, L. D., Guilam, M. C. R., \& Ferreira, M. S. (2010). Correndo o risco: uma introdução aos riscos em saúde (134 p.). Rio de Janeiro: Ed. Fiocruz. http://dx.doi.org/10.7476/9788575413104.

Castro, B. S., Young, C. E. F., \& Lima, G. R. (2014). A percepção pública de risco alimentar e os organismos geneticamente modificados no Brasil. Estudos Sociedade e Agricultura, 22(1), 164-19. Retrieved from http://www.ie.ufrj.br/images/gema/Gema_Monografias/4721246-1-PB.pdf

Chambers, V. E., Chambers, I. V. E. 4th, \& Castro, M. (2018). What Is "Natural"? Consumer responses to selected ingredients. Foods, 7(4), 1-10. http://dx.doi.org/10.3390/foods7040065. PMid:29690627.

Charlebois, S., \& Summan, A. (2015). A risk communication model for food regulatory agencies in modern society. Trends in Food Science \& Technology, 45(1), 153-165. http://dx.doi.org/10.1016/j. tifs.2015.05.004.

Chen, M. F. (2017). Modeling an extended theory of planned behavior model to predict intention to take precautions to avoid consuming food with additives. Food Quality and Preference, 58, 24-33. http:// dx.doi.org/10.1016/j.foodqual.2017.01.002.

Chen, M. F. (2018). Social representations of genetically modified foods and public willingness to consume such foods in Taiwan. Journal of the Science of Food and Agriculture, 98(14), 5428-5434. http:// dx.doi.org/10.1002/jsfa.9086. PMid:29675854.

Cho, H., Reimer, T., \& McComas, K. A. (Ed.) (2014). The SAGE handbook of risk communication. (376 p.). London: Sage Publications Inc.

Conselho de Informações sobre Biotecnologia - CIB. (2016). Pesquisa Conecta/Ibope. Retrieved from http://www.mundocoop.com.br/ wp-content/uploads/2018/08/Ibope.Volume_Final.pdf

Coulibaly, O., Nouhoheflin, T., Aitchedji, C. C., Cherry, A. J., \& Adegbola, P. (2011). Consumers' perceptions and willingness to pay for organically grown vegetables. International Journal of 
Vegetable Science, 17(4), 349-362. http://dx.doi.org/10.1080/1931 5260.2011 .563276 .

Covello, V. T., \& Mumpower, J. (1985). Risk analysis and risk management: an historical perspective. Risk Analysis, 2(2), 103-120. http://dx.doi. org/10.1111/j.1539-6924.1985.tb00159.x.

Ditlevsen, K., Sandøe, P., \& Lassen, J. (2019). Healthy food is nutritious, but organic food is healthy because it is pure: the negotiation of healthy food choices by Danish consumers of organic food. Food Quality and Preference, 71, 46-53. http://dx.doi.org/10.1016/j. foodqual.2018.06.001.

Etienne, J., Chirico, S., McEntaggart, K., Papoutsis, S., \& Millstone, E. (2018). EU Insights - Consumer perceptions of emerging risks in the food chain (External Scientific Report, 81 p.). Parma: EFSA Supporting Publication. http://dx.doi.org/10.2903/sp.efsa.2018.EN-1394.

European Commission (2010). Special Eurobarometer 354: food-related risks. Brussels: TNS Opinion \& Social. Retrieved from https://ec.europa. eu/commfrontoffice/publicopinion/archives/ebs/ebs_354_en.pdf

European Commission (2014). JRC foresight study: tomorrow's healthy society - research priorities for foods and diets. (Final Report). Bruxelles: Joint Research Centre. Retrieved from https://ec.europa.eu/jrc/sites/ $\mathrm{jrcsh} /$ files/jrc-study-tomorrow-healthly-society.pdf

European Commission (2019). Special Eurobarometer Wave EB91.3: food safety in the EU. Brussels: TNS Opinion \& Social. Retrieved from https://www.efsa.europa.eu/sites/default/files/corporate_publications/ files/Eurobarometer2019_Food-safety-in-the-EU_Full-report.pdf

Fife-Schaw, C., \& Rowe, G. (1996). Public perceptions of everyday food hazards: a psychometric study. Risk Analysis, 16(4), 487-500. http:// dx.doi.org/10.1111/j.1539-6924.1996.tb01095.x. PMid:8819341.

Frewer, L. J., Fischer, A. R. H., Brennan, M., Bánáti, D., Lion, R., Meertens, M., Rowe, G., Siegrist, M., Verbeke, W., \& Vereijken, C. M. J. L. (2016). Risk/Benefit communication about food - A systematic review of the literature. Critical Reviews in Food Science and Nutrition, 56(10), 1728-1745. http://dx.doi.org/10.1080/1040 8398.2013.801337. PMid:25575335.

Glik, D. C. (2007). Risk communication for public health emergencies. Annual Review of Public Health, 28(1), 33-54. http://dx.doi.org/10.1146/ annurev.publhealth.28.021406.144123. PMid:17222081.

Hansson, S. O. (2010). Risk: objective or subjective, facts or values. Journal of Risk Research, 13(2), 231-238. http://dx.doi. org/10.1080/13669870903126226.

Hartmann, C., Hübner, P., \& Siegrist, M. (2018a). A risk perception gap? Comparing expert, producer and consumer prioritization of food hazard controls. Food and Chemical Toxicology, 116(Pt B), 100107. http://dx.doi.org/10.1016/j.fct.2018.04.006. PMid:29626580.

Hartmann, C., Hieke, S., Taper, C., \& Siegrist, M. (2018b). European consumer healthiness evaluation of 'Free-form' labelled food products. Food Quality and Preference, 68, 377-388. http://dx.doi. org/10.1016/j.foodqual.2017.12.009.

Hilverda, F., \& Kuttschreuter, M. (2018). Online information sharing about risks: the case of organic food. Risk Analysis, 38(9), 1-17. http://dx.doi.org/10.1111/risa.12980. PMid:29570833.

Hilverda, F., Kuttschreuter, M., \& Giebels, E. (2018). The effect of online social proof regarding organic food: comments and likes on Facebook. Frontiers in Communication, 3, 1-15. http://dx.doi. org/10.3389/fcomm.2018.00030.

Hooker, C., Capon, A., \& Leask, J. (2017). Communicating about risk: strategies for situations where public concern is high but the risk is low. Public Health Research \& Practice, 27(1), e2711709. http:// dx.doi.org/10.17061/phrp2711709. PMid:28243675.
Kahneman, D., \& Frederick, S. (2005). A model of heuristic judgment. In K. J. Holyoak, \& R. G. Morrison (Eds.), The Cambridge handbook of thinking and reasoning (pp. 267-93). New York: Cambridge University Press.

Kaptan, G., Fischer, A. R. H., \& Frewer, L. J. (2018). Extrapolating understanding of food risk perceptions to emerging food safety cases. Journal of Risk Research, 21(8), 996-1018. http://dx.doi.org/ 10.1080/13669877.2017.1281330.

Kasperson, R. E., Renn, O., Slovic, P., Brown, H. S., Emel, J., Goble, R., Kasperson, J. X., \& Ratick, S. (1988). The social amplification of risk: a conceptual framework. Risk Analysis, 8(2), 177-187. http:// dx.doi.org/10.1111/j.1539-6924.1988.tb01168.x.

Kermisch, C. (2012). Risk and responsibility: a complex and evolving relationship. Science and Engineering Ethics, 18(1), 91-102. http:// dx.doi.org/10.1007/s11948-010-9246-y. PMid:21103951.

Kher, S. V., De Jonge, J., Wentholt, M. T. A., Deliza, R., Andrade, J. C., Cnossen, H. J., Luijckx, N. B. L., \& Frewer, L. J. (2013). Consumer perceptions of risks of chemical and microbiological contaminants associated with food chains: a cross-national study. International Journal of Consumer Studies, 37(1), 73-83. http://dx.doi.org/10.1111/ j.1470-6431.2011.01054.x.

Koch, S., Epp, A., Lohmann, M., \& Böl, G. F. (2017). Pesticide residues in food: attitudes, beliefs, and misconceptions among conventional and organic consumers. Journal of Food Protection, 80(12), 2083-2089. http://dx.doi.org/10.4315/0362-028X.JFP-17-104. PMid:29154718.

Komoto, K., Okamoto, S., Hamada, M., Obana, N., Samori, M., \& Imamura, T. (2016). Japanese consumer perceptions of genetically modified food: findings from an international comparative study. Interactive Journal of Medical Research, 5(3), 1-27. http://dx.doi. org/10.2196/ijmr.5850. PMid:27573588.

Lanard, J. (2004). A quick introduction to risk perception. In P. M. Sandman. Risk communication: facing public outrage. USA: The Peter Sandman Risk Communication Website. Retrieved from https://pdfs.semanticscholar.org/094d/416a506841d7e26630a86e 0bbe5adbd40c5f.pdf

Loebnitz, N., \& Grunert, K. G. (2018). The impact of abnormally shaped vegetables on consumers' risk perception. Food Quality and Preference, 63, 80-87. http://dx.doi.org/10.1016/j.foodqual.2017.08.004.

Mallinson, L., Russell, J., Cameron, D. D., Ton, J., Horton, P., \& Barker, M. E. (2018). Why rational argument fails the genetic modification (GM) debate. Food Security, 10(5), 1145-1161. http://dx.doi. org/10.1007/s12571-018-0832-1.

Meagher, K. D. (2018). Public perceptions of food-related risks: a cross-national investigation of individual and contextual influences. Journal of Risk Research, 22(7), 919-935. http://dx.doi.org/10.1080/ 13669877.2017.1422789.

Omari, R., Frempong, G. K., \& Arthur, W. (2018). Public perceptions and worry about food safety hazards and risks in Ghana. Food Control, 93, 76-82. http://dx.doi.org/10.1016/j.foodcont.2018.05.026.

Patel, M. (2018). Social research strategies to explore trust in food and its regulator. In EFSA Conference 2018. Parma: EFSA. Retrieved from https://www.efsa.europa.eu/sites/default/files/event/180918conference/presentations/20-2_15_Patel.pdf

Petrun, E. L., Flood, A., Sellnow, T. L., Edge, M. S., \& Burns, K. (2015). Shaping health perceptions: communicating effectively about chemicals in food. Food Protection Trends, 35(1), 24-35. Retrieved from https://pdfs. semanticscholar.org/e292/f6fdb2c41e92e795c1c59711be80888e2737.pdf

Pimenta, S.F. (2003) Percepção da população do Distrito Federal quanto ao risco da presença de contaminantes químicos em alimentos (Monografia). Universidade de Brasília, Brasília. 
Renn, O., Jaeger, C., Rosa, E., \& Webler, T. (2001). The rational actor paradigm in risk theories: analysis and critique. In M. J. Cohen (Ed.), Risk in the modern age: social theory, science, and environmental decision-making. New York: Palgrave, p. 1-21.

Rijksinstituut voor Volksgezondheid en Milieu - RIVM. (2017). What is on our plate? Safe, healthy and sustainable diets in the Netherlands (RIVM Report 2017-0024). Bilthoven: National Institute for Public Health and the Environment. http://dx.doi.org/10.21945/RIVM2017-0024.

Saba, A., \& Messina, F. (2003). Attitudes towards organic foods and risk/benefit perception associated with pesticides. Food Quality and Preference, 14(8), 637-645. http://dx.doi.org/10.1016/S09503293(02)00188-X.

Sandman, P. M. (2012). Responding to community outrage: strategies for effective risk communication (143 p.). Falls Church: AIHA Press. Retrieved from http://petersandman.com/media/ RespondingtoCommunityOutrage.pdf

Slovic, P., Fischhoff, B., \& Lichtenstein, S. (1980). Facts and fears: understanding perceived risk. In R. C. Schwing, \& W. A. Albers (Eds.), Societal risk assessment (pp. 181-216). Boston: Springer. http://dx.doi.org/10.1007/978-1-4899-0445-4_9.

Song, H., \& Schwarz, N. (2009). If it's difficult to pronounce, it must be risky. Psychological Science, 20(2), 135-138. http://dx.doi. org/10.1111/j.1467-9280.2009.02267.x. PMid:19170941.

Sparks, P., \& Shepherd, R. (1994). Public perceptions of the potential hazards associated with food production and food consumption: an empirical study. Risk Analysis, 14(5), 799-806. http://dx.doi. org/10.1111/j.1539-6924.1994.tb00291.x. PMid:7800864.

Spencer, T. (Ed.) (2016). Risk perception: theories and approaches (133 p.). New York: Nova Science Publishers.

Starr, C. (1969). Social benefit versus technological risk. Science, 165(3899), 1232-1238. http://dx.doi.org/10.1126/science.165.3899.1232. PMid:5803536.
Szűcs, V., Szabó, E., Guerrero, L., Tarcea, M., \& Bánáti, D. (2019). Modelling of avoidance of food additives: a cross country study. International Journal of Food Sciences and Nutrition, 16(8), 1-13. http://dx.doi.org/10.1080/09637486.2019.1597837. PMid:30987483.

Tonkin, E., Coveney, J., Meyer, S. B., Wilson, A. M., \& Webb, T. (2016). Managing uncertainty about food risks - Consumer use of food labelling. Appetite, 107, 242-252. http://dx.doi.org/10.1016/j. appet.2016.08.015. PMid:27524658.

van Gunst, A., \& Roodenburg, A. J. C. (2019). Consumer distrust about E-numbers: a qualitative study among food experts. Foods, 8(5), 178. http://dx.doi.org/10.3390/foods8050178. PMid:31137800.

Visschers, V. H. M., \& Siegrist, M. (2018). Differences in risk perception between hazards and between individuals. In M. Raue, E. Lermer, \& B. Streicher (Eds.), Psychological perspectives on risk and risk analysis - theory, models, and applications (pp. 1-27). Cham: Springer. http://dx.doi.org/10.1007/978-3-319-92478-6_3.

Völker, C., Kramm, J., Kerber, H., Schramm, E., Winker, M., \& Zimmermann, M. (2017). More than a potential hazard - approaching risks from a social-ecological perspective. Sustainability, 9(7), 1039. http://dx.doi.org/10.3390/su9071039.

Wiedemann, P. M. (1993). Introduction risk perception and communication. Jülich: Arbeiten Zur Risko-Kommunikation Heft 38.

Wunderlich, S., \& Gatto, K. A. (2015). Consumer perception of genetically modified organisms and sources of information. Advances in Nutrition, 6(6), 842-851. http://dx.doi.org/10.3945/an.115.008870. PMid:26567205.

Yan, Z., Huang, Z., Wang, Y., \& Zhou, J. (2019). Are social embeddedness associated with food risk perception under media coverage? Journal of Integrative Agriculture, 18(8), 1804-1819. http://dx.doi.org/10.1016/ S2095-3119(19)62586-4.

You, M., Lim, J., Shim, M., \& Ju, Y. (2018). Outrage factors on food risk perception as moderated by risk attitude. Journal of Risk Research, 22(12), 1522-1531. http://dx.doi.org/10.1080/13669877.2018.1501591. 